\title{
Research on Influencing Factors of Innovation and Entrepreneurship Education System in Application-Oriented Universities
}

\author{
Pengzhong Dong ${ }^{1, a}$ and Limeng Dong ${ }^{2, b}$ \\ ${ }^{1}$ Jilin Teachers'Instiute of Engineering and Technology, Changchun,Jilin , China \\ ${ }^{2}$ Harbin Institute of Technology, Harbin,HeiLongjiang, China \\ a414388426@qq.com, bsf7988@163.com
}

Keywords: Entrepreneurship education system; University innovation; Education system orientation, Education system frame design

\begin{abstract}
In the process of establishing the education system of innovation and entrepreneurship in the applied universities, we can draw lessons from the theories and thoughts of the stakeholders. In combination with the characteristics, objectives and the concept of stakeholders of innovative and entrepreneurial education in applied universities, This paper holds that the stakeholders of innovative and entrepreneurial education system in applied universities can be defined as: benefit or damage from the development plan and implementation activities of college students' innovative and entrepreneurial education; People or groups that can affect the key and goals of innovative and entrepreneurial education of college students or are affected by the realization of the objectives of innovative and entrepreneurial education are all stakeholders in the system of innovative and entrepreneurial education.
\end{abstract}

\section{Foreword}

Since 1963, when a research group at Stanford University first defined stakeholders, there are many concepts about stakeholders, of which Freeman's definition is the most representative. In its book Strategic Management: a stakeholder approach, stakeholders are defined as people who can influence the achievement of an organization's goals or can be influenced by the processes through which the organization achieves them. Since the 1990s, many scholars have put forward their own views from different perspectives: the stakeholders are those groups that have a legitimate claim on the enterprise; they are established through the existence of an exchange relationship. That is, they provide enterprises with critical resources in exchange for their personal interests to meet the goal[1,2]. They believe that the stakeholders invest some physical capital, human capital, financial capital or some valuable things in the enterprise, and therefore bear some form of risk; or they assume the risk as a result of the business activities.

\section{Analysis of stakeholders in the Teaching system of Innovation and Entrepreneurship in Application-oriented Universities}

There are many aspects involved in the construction, implementation and improvement of the innovative and entrepreneurial education system[3]. According to the questionnaire survey and the analysis results of the innovative and entrepreneurial education system.

The main body includes: the school itself, the institute (department), the school scientific research institution, the university student, the teacher; the object includes: the school party committee organization, the administrative organization, the teaching auxiliary organization, the government, the social organization, the party committee personnel, the administrative organization personnel[4-6].

Now applied university organization is a complex group of interests, it involves the government, the university itself, faculty, students and service personnel and other interests. According to the different causes of conflict, it can be divided into two categories: conflict of interest and conflict of ideas. The former refers to the conflict between internal stakeholder groups and external stakeholder 
groups, mainly reflected in the conflict between the school and the government; while most of the conflicts between individuals are the conflicts between concepts, administrative organizations and teachers, students[7].

\section{Research project design}

Choice of research methods. The main purpose of this project is to objectively understand the basic situation of the development and implementation of innovative and entrepreneurial education in research and application universities in our country, to explore the influencing factors of innovative and entrepreneurial education, and to design the rules that are in line with the training of innovative and entrepreneurial talents.

Questionnaire design.There are three types in the design of the questionnaire: the questionnaire on innovation and entrepreneurship education in colleges and universities (Students), the questionnaire of innovative and entrepreneurial education in institutions of higher learning (graduates), the questionnaire of innovative and entrepreneurial education in institutions of higher learning (teachers). For different subjects, we use different forms of questions according to different emphasis.

Questionnaire statistics.A total of 500 questionnaires were sent out, 486 were recovered, and 457 valid questionnaires were selected, accounting for $91.4 \%$. Of the valid questionnaires, 221 were from students, accounting for $48.36 \%$ of the total effective questionnaires; 107 were from graduates, accounting for $23.41 \%$ of the total effective questionnaires; and 129 were from teachers, accounting for $28.23 \%$ of the total effective questionnaires.

Using Excel for a preliminary analysis of the data, the structural distribution of the sample can be obtained, as shown in Table 1, Table 2,Table 3.

Table 1

\begin{tabular}{|c|c|c|c|}
\hline Category & Sample number & Percentage & Total \\
\hline
\end{tabular}

Distribution of sample structure of questionnaire (students at school)

\begin{tabular}{|c|c|c|c|c|}
\hline \multicolumn{2}{|c|}{ Category } & Sample number & Percentage & Total \\
\hline \multirow{2}{*}{ Gender } & Male & 61 & $57.01 \%$ & \multirow{2}{*}{107} \\
\hline & Female & 46 & $42.99 \%$ & \\
\hline \multirow{2}{*}{ Degree } & $\begin{array}{l}\text { Undergradu } \\
\text { ate course }\end{array}$ & 64 & $59.81 \%$ & \multirow[t]{2}{*}{107} \\
\hline & Master & 43 & $40.17 \%$ & \\
\hline \multirow{6}{*}{$\begin{array}{c}\text { Professional } \\
\text { category }\end{array}$} & $\begin{array}{c}\text { Neo-Confuc } \\
\text { ianism }\end{array}$ & 14 & $13.08 \%$ & \multirow{6}{*}{107} \\
\hline & Engineering & 46 & $42.99 \%$ & \\
\hline & $\begin{array}{l}\text { Manageme } \\
\text { nt science }\end{array}$ & 27 & $25.23 \%$ & \\
\hline & Grammar & 11 & $10.28 \%$ & \\
\hline & Agronomy & 3 & $2.80 \%$ & \\
\hline & Medicine & 6 & $5.61 \%$ & \\
\hline
\end{tabular}

Table 2 Distribution of sample structure of questionnaire (graduates) 


\begin{tabular}{|c|c|c|c|c|c|}
\hline \multirow{4}{*}{\multicolumn{2}{|c|}{ Table 3}} & Male & 123 & $55.66 \%$ & \multirow{2}{*}{221} \\
\hline & & Female & 98 & $44.34 \%$ & \\
\hline & & $\begin{array}{l}\text { Undergradu } \\
\text { ate course }\end{array}$ & 129 & $58.37 \%$ & \multirow{2}{*}{221} \\
\hline & & Master & 92 & $41.63 \%$ & \\
\hline & \multirow{6}{*}{$\begin{array}{c}\text { Professional } \\
\text { category }\end{array}$} & $\begin{array}{l}\text { Neo-Confuci } \\
\text { anism }\end{array}$ & 41 & $18.55 \%$ & \multirow{6}{*}{221} \\
\hline & & Engineering & 73 & $33.03 \%$ & \\
\hline & & $\begin{array}{l}\text { Manageme } \\
\text { nt science }\end{array}$ & 61 & $27.60 \%$ & \\
\hline & & Grammar & 27 & $12.22 \%$ & \\
\hline & & Agronomy & 7 & $3.17 \%$ & \\
\hline & & Medicine & 12 & $5.43 \%$ & \\
\hline & \multicolumn{2}{|c|}{ Category } & Sample number & Percentage & Total \\
\hline & \multirow{2}{*}{ Gender } & Male & 57 & $44.19 \%$ & \multirow{2}{*}{129} \\
\hline & & Female & 72 & $55.81 \%$ & \\
\hline & \multirow{2}{*}{ Degree } & $\begin{array}{l}\text { Undergradu } \\
\text { ate course }\end{array}$ & 61 & $47.29 \%$ & \multirow[t]{2}{*}{129} \\
\hline & & Master & 68 & $52.71 \%$ & \\
\hline & \multirow{6}{*}{$\begin{array}{c}\text { Professional } \\
\text { category }\end{array}$} & $\begin{array}{l}\text { Neo-Confuci } \\
\text { anism }\end{array}$ & 26 & $20.16 \%$ & \multirow{6}{*}{129} \\
\hline & & Engineering & 29 & $22.48 \%$ & \\
\hline & & $\begin{array}{l}\text { Manageme } \\
\text { nt science }\end{array}$ & 41 & $31.78 \%$ & \\
\hline & & Grammar & 22 & $17.05 \%$ & \\
\hline & & Agronomy & 2 & $1.55 \%$ & \\
\hline & & Medicine & 9 & $6.98 \%$ & \\
\hline & \multicolumn{2}{|c|}{ Category } & Sample number & Percentage & Total \\
\hline & \multirow{2}{*}{ Gender } & Male & 57 & $44.19 \%$ & \multirow{2}{*}{129} \\
\hline & & Female & 72 & $55.81 \%$ & \\
\hline & \multirow[t]{2}{*}{ Degree } & $\begin{array}{l}\text { Undergradu } \\
\text { ate course }\end{array}$ & 61 & $47.29 \%$ & \multirow[t]{2}{*}{129} \\
\hline & & Master & 68 & $52.71 \%$ & \\
\hline & \multirow{6}{*}{$\begin{array}{c}\text { Professional } \\
\text { category }\end{array}$} & $\begin{array}{l}\text { Neo-Confuci } \\
\text { anism }\end{array}$ & 26 & $20.16 \%$ & \multirow{6}{*}{129} \\
\hline & & Engineering & 29 & $22.48 \%$ & \\
\hline & & $\begin{array}{l}\text { Manageme } \\
\text { nt science }\end{array}$ & 41 & $31.78 \%$ & \\
\hline & & Grammar & 22 & $17.05 \%$ & \\
\hline & & Agronomy & 2 & $1.55 \%$ & \\
\hline & & Medicine & 9 & $6.98 \%$ & \\
\hline
\end{tabular}

Distribution of sample structure of questionnaire (graduates)

This project uses the commonly used reliability test method coefficient test, through the scale measured results of homogeneity test to investigate the internal consistency of the questionnaire level, it is generally believed that the higher the reliability of the scale; The more stable the measurement results are. Furthermore, the accepted acceptable metric value is 0.7 . According to the 
measured results, we can see that the reliability of each part of the three questionnaires are higher than, indicating that the reliability and consistency of the questionnaire are high, and the design of the questionnaire is ideal. only when each load coefficient is greater than 0.5 , and the statistical value KMO> 0.5, Bartlett \& LTH 0.01; Only then can we use factor analysis to combine the options of the questions in the questionnaire into one factor for analysis. Through statistical calculation and analysis, it is concluded that all KMO coefficients are greater than 0.5 , all loads are greater than 0.5 , and all of them have passed the Btrtlett test, which shows that all the options have good discrimination, and at the same time, all the explanatory quantities are above, indicating that the structure is reasonable; Basically meet the requirements.

Structural equation Modeling Analysis of data.The use of structural equation software LISREL to analyze the relevant data requires the use of maximum likelihood estimation, so the sample size is required to reach a certain scale. The effective sample number of this questionnaire survey is 486 \& GT, 100, which meets the requirements. Generally speaking, the overall fitting degree of a model includes three aspects, namely, absolute fitting degree, value-added fitting degree and simple fitting degree. According to the analysis of model data, each index of the model is in an ideal state. Therefore, it can be considered that the selected samples have a high degree of fit with the preset of the model, and there is no obvious difference between the observed values and the estimated values in the covariance matrix. Finally, the verification results of the structural equation analysis software operation, as shown in Table 4.

Table 4 Validation of model assumptions

\begin{tabular}{|c|c|c|c|}
\hline Model hypothesis & $\begin{array}{c}\text { Parameter estimati } \\
\text { on }\end{array}$ & $T$ & Conclusion \\
\hline $\begin{array}{l}\text { EP-BW: Innovation and Entrepreneurship Education incent } \\
\text { ive and support Policy has a significant positive impact } \\
\text { on College students' Entrepreneurship intention }\end{array}$ & $\xi 11=0.18$ & 2.32 & Support \\
\hline $\begin{array}{l}\text { EP-AF:The positive effect of Innovation and Entrepreneurs } \\
\text {-hip Education incentive and support Policy on all aspect } \\
\text { s of Innovation and Entrepreneurship of College students }\end{array}$ & $\xi 12=0.62$ & 3.81 & Support \\
\hline $\begin{array}{l}\text { RD-BW: The allocation of innovative and entrepreneurial } \\
\text { resources in colleges and universities has a significant } \\
\text { positive impact on college students' willingness to innova } \\
\text { te and start a business. }\end{array}$ & $\xi 21=0.29$ & 2.91 & Support \\
\hline $\begin{array}{l}\text { RD-AF: The positive effect of the allocation of Innovation } \\
\text { and Entrepreneurship Resources on the Innovation and } \\
\text { Entrepreneurship of College students }\end{array}$ & $\xi 22=0.22$ & 2.59 & Support \\
\hline $\begin{array}{l}\text { RD-IW: The allocation of Innovation and Entrepreneurship } \\
\text { Resources in Colleges and Universities has a significant } \\
\text { positive impact on the implementation of Innovation and } \\
\text { Entrepreneurship Education }\end{array}$ & $\xi 23=0.18$ & 2.32 & Support \\
\hline $\begin{array}{l}\text { RD-BW: The allocation of innovative and entrepreneurial } \\
\text { resources in colleges and universities has a significant po } \\
\text { sitive impact on college students' willingness to innovate } \\
\text { and start a business }\end{array}$ & $\xi 31=0.31$ & 3.02 & Support \\
\hline $\begin{array}{l}\text { AD-AF: The degree of emphasis on College students' } \\
\text { Innovation and Entrepreneurship has a significant positive } \\
\text { impact on all aspects of College students' Innovation an } \\
\text { d Entrepreneurship }\end{array}$ & $\xi 32=-0.05$ & -0.14 & Support \\
\hline $\begin{array}{l}\text { AD-IW: The degree of emphasis on college students' } \\
\text { innovation and entrepreneurship has a significant positive } \\
\text { impact on the implementation of college students' innov } \\
\text { ation and entrepreneurship education. }\end{array}$ & $\xi 33=-0.13$ & -1.29 & Support \\
\hline $\begin{array}{l}\text { IW-AF: The positive influence of the implementation way } \\
\text { of College students' Innovation and Entrepreneurship Ed } \\
\text { ucation on all aspects of College students' Innovation } \\
\text { and Entrepreneurship }\end{array}$ & $\xi 32=0.11$ & 1.84 & Support \\
\hline
\end{tabular}

As can be seen from Figure 1.4, the estimated values and values of the parameters of the path and the path are both negative, so the path is not significant and needs to be corrected. The fitting degree of modified model is still very high; for the reduced degree of fit, PNFI and PGFI are greater than 
0.5, meeting the parsimonious standard of fit; in terms of value-added fitting, NFI, NNFI, CFI are greater than 0.9, also reached the ideal state. According to the results of the model modification, the main influencing factors of the innovation and entrepreneurship education system of applied universities can be obtained by removing the factors of little influence, as shown in the Table 5:

Table 5 Main influencing factors of innovative and entrepreneurial education system in application-oriented universities

\begin{tabular}{|c|c|}
\hline First level indicator & Main influencing factors \\
\hline \multirow{2}{*}{ Entrepreneurial will } & Entrepreneurial idea source \\
\hline & Entrepreneurial purpose \\
\hline \multirow{4}{*}{$\begin{array}{c}\text { Influencing factors of Innovation and } \\
\text { Entrepreneurship }\end{array}$} & Support at all levels \\
\hline & School help \\
\hline & Entrepreneurial difficulties \\
\hline & $\begin{array}{c}\text { Cultivate the channel of innovation and } \\
\text { pioneering ability }\end{array}$ \\
\hline \multirow{2}{*}{$\begin{array}{c}\text { Degree of attention to innovation and } \\
\text { entrepreneurship }\end{array}$} & $\begin{array}{c}\text { The importance of Innovation and } \\
\text { Entrepreneurship Education }\end{array}$ \\
\hline & $\begin{array}{c}\text { The goal of innovation and entrepreneurship } \\
\text { education }\end{array}$ \\
\hline \multirow{4}{*}{$\begin{array}{c}\text { Allocation of innovative and entrepreneurial } \\
\text { resources }\end{array}$} & $\begin{array}{c}\text { Offering courses related to Innovation and } \\
\text { Entrepreneurship }\end{array}$ \\
\hline & Teachers of innovative entrepreneurship education \\
\hline & Innovation and entrepreneurship guidance \\
\hline & $\begin{array}{c}\text { Lack of innovative and entrepreneurial education } \\
\text { resources }\end{array}$ \\
\hline \multirow{4}{*}{$\begin{array}{l}\text { Innovating the way of carrying out Entrepreneurship } \\
\text { Education }\end{array}$} & Innovative and entrepreneurial education content \\
\hline & Innovative and entrepreneurial training mode \\
\hline & $\begin{array}{c}\text { Innovative Entrepreneurship course Teaching } \\
\text { Mode }\end{array}$ \\
\hline & Entrepreneurial practice form \\
\hline \multirow{2}{*}{$\begin{array}{l}\text { Encouraging and supporting College students' } \\
\text { Innovation and Entrepreneurship }\end{array}$} & $\begin{array}{l}\text { Incentive Mechanism of Innovation and } \\
\text { Entrepreneurship Education }\end{array}$ \\
\hline & Government support policy \\
\hline
\end{tabular}

\section{Conclusion}

According to the measured results, the reliability of each part of the three questionnaires are higher than that of the questionnaire, indicating that the reliability and consistency of the questionnaire are high, all options have a good discrimination, at the same time, each explanation is above, indicating that the structure is reasonable.

The whole fitting degree of the model includes three aspects: the absolute fitting degree, the increment fitting degree and the simple fitting degree. According to the analysis of model data, each index of the model is in an ideal state. Therefore, it can be considered that the selected samples have a high degree of fit with the preset of the model, and there is no obvious difference between the observed values and the estimated values in the covariance matrix. The modified model fit degree is still very high; and for the parsimony fit meet the parsimony fitting standard; in the value-added fit, also reached the ideal state.

\section{Acknowledgements}

Jilin provincial department of education social science project 2017.Project name: Study on education system for innovation and entrepreneurship in application-oriented universities (special employment project). Project number: JJKH2017184SK

\section{Reference documentation}

[1] Roediger Voss, Thorsten Gruber,Isabelle Szmigin.Service quality in higher education: The role of student expectations[J].Journal of Business Research . 2007(9). 
[2] Alexander Ardichvili,Richard Cardozo,Sourav Ray.A theory of entrepreneurialopportunity identification and development[J].Journal of Business Venturing.2003(1).

[3] Jerome A Katz.The chronology and intellectual trajectory of American entrepreneurship education[J]. Journal of Business Venturing . 2002 (2).

[4] Claire M. Leitch,Richard T. Harrison.A process model for entrepreneurship education and development[J].International Journal of Entrepreneurial Behaviour \& Research . 1999 (3).

[5] Thinking Piece-creating the entrepreneurial university of the 21st century. Atnerton A. Entre News . 2004.

[6] Jock Collins. Cultural diversity and entrepreneurship: policy responses to immigrant entrepreneurs in Australia[J]. Entrepreneurship \& Regional Development.2003 (2).

[7] Nancy M Carter,William B Gartner,Kelly G Shaver,Elizabeth J Gatewood.The career reasons of nascent entrepreneurs[J].Journal of Business Venturing.2002 (1). 